\title{
Ratification as accommodation? Domestic dissent and human rights treaties
}

\author{
Kirssa Cline Ryckman \\ School of Government and Public Policy, University of Arizona
}

\begin{abstract}
Repression is the expected response to anti-government protest; however, leaders can also accommodate demonstrators. Committing to human rights treaties is considered in this environment, where treaty commitments are conceptualized as a policy concession that leaders can grant dissenters. Past research has shown that top-down domestic pressures, such as new democratic regimes, can influence treaty commitments. This article extends this line of research by considering the influence of bottom-up domestic pressure, arguing that nonviolent, pro-democracy movements can pressure leaders into concessions, as these movements are risky to repress but threatening to ignore. Leaders are expected to seek 'cheap' accommodations and commitments to human rights treaties provide a relatively low-cost concession that also addresses demonstrators' pro-democracy demands. Using commitments to the nine core UN human rights treaties, results are generally supportive. Governments experiencing a nonviolent, prodemocracy movement are consistently likely to sign human rights treaties. Ratification is also likely but in more limited contexts, and is more closely related to movement success. This suggests that bottom-up pressures can influence commitment to human rights treaties, but there may be little substance behind those concessions. The status quo and cost-adverse preferences of leaders lead them to grant accommodations that result in minimal change and cost.
\end{abstract}

Keywords: protest, repression, accommodation, human rights treaties, nonviolence Corresponding author: klcline@email.arizona.edu 


\section{Introduction}

While repression is an expected response to protest (e.g., Davenport, 2007), coercion is one of many alternatives a leader can choose to address the dissenters. A state can accommodate and grant concessions to the demonstrators in attempt to end ongoing protest. This strategic response, however, is less widely studied (Carey, 2006). In part this reflects the complexity in capturing positive responses, given the wide-range of potential government actions and the difficulty in measuring these responses as compared to behavioral actions such as detention and killing. It also reflects the importance of understanding when a government will kill, torture, or otherwise repress its citizens.

Yet accommodation is also an important policy response. A better understanding of concessions can contribute to our understanding of how leaders manoeuver to stay in power and when demonstrators are likely to win policy concessions. Granting accommodations also denotes a willingness to alter the status quo and engage in nonviolent compromise, the basis of democratic governance. This makes even superficial concessions part of a democratic process that may serve as a foundation upon which democratic institutions can be built (Chenoweth \& Stephan, 2011). Unforeseen consequences of concessions like treaty ratification can also have wide-reaching consequences, such as mobilizing domestic opposition forces against treaty violations and changing the nature of demands that these domestic actors are willing to make, while international actors may also pressure states for their human rights violations (Simmons, 2009; Risse \& Sikkink, 1999).

To address the question of when accommodation is likely in the face of dissent, I consider the puzzle of human rights treaty ratification, conceptualizing treaty commitments as a form of policy concession that leaders can offer to protesters. Past research has found that domestic pressures can produce treaty commitments, including arguments of democratic lock-in (e.g. Mansfield \& Pevehouse, 2006, 2008; Hafner-Burton, Mansfield \& Pevehouse, 2015) and pressure from opposition parties within dictatorships to grant concessions (Vreeland, 2008). 
I argue that bottom-up pressure can also produce treaty commitments, ${ }^{1}$ specifically in the form of large, nonviolent, pro-democracy campaigns. Large movements are difficult to ignore, and can generate a short time-horizon for leaders who are keen to end the anti-regime threat (Risse \& Sikkink, 1999). Movements that are nonviolent are also more difficult for governments to repress due to the backlash potential of repression, which can ultimately strengthen the group. There are also logistical difficulties with repressing a particularly large movement with many thousand participants. It is thus expected that when repression and tolerance become unattractive strategies, as with large and nonviolent movements, that concessions are likely to be granted.

In addition to size and tactics, the demands of the movement are also important. Existing research suggests that maximalist demands decrease the likelihood that protesters will achieve policy concessions (Franklin, 2009; O'Keefe \& Schumaker, 1983; Schumaker, 1975). Counter to this expectation, I argue that pro-democracy goals increase the chances of treaty commitments. Leaders seek to maintain the status quo, and to only give small concessions that do not require significant change. As a result, governments are not expected to offer more than dissenters demand. While demands for democracy constitute a maximalist goal, treaty commitments directly address human rights, but do so in a low-cost manner. It is expected that large, nonviolent movements with democracy goals will increase the likelihood of treaty commitments.

To proceed, the following section overviews the literature on the protest-repression nexus, with a discussion of accommodation as a policy response. The existing literature on human rights treaty ratification is then considered, focusing on domestic influences on joining treaties. This is followed by a discussion of when accommodation and specifically treaty commitments are likely, and the case of Chile's nonviolent movement against Pinochet is used to illustrate how these domestic pressures can result in human rights treaty commitments, in this case the signature and ratification of the Convention Against Torture. Hypotheses are

\footnotetext{
${ }^{1}$ The UN's core human rights treaties are included, overviewed in Table I.
} 
tested using the signature and ratification of the nine core UN human rights treaties, as well as nonviolent movements coded by the Nonviolent and Violent Campaigns and Outcomes 2.0 (NAVCO) data project (Chenoweth \& Lewis, 2013). Results are generally supportive, although suggest that there are differences between signing and ratification. Nonviolent campaigns consistently increase the likelihood of signing human rights treaties across different model specifications; ratification is also likely but in more limited contexts, and is more closely related to movement success. This underscores the cost-adverse nature of leaders as they attempt to maintain the status quo. The final section presents a discussion of the results and larger conclusions on both responses to dissent and treaty commitments.

\section{Government responses to dissent}

Within the repression literature, it is widely accepted that leaders will use repression as threats, real or perceived, mount (Gurr, 1986; Poe \& Tate, 1994). Davenport (2007) notes that in nearly every study that examines the effect of dissent on government action, increased protest leads to increased repression. He terms this the 'Law of Coercive Responsiveness,' denoting a relationship so consistent it verges on law. While threats to a leader's rule can vary considerably, any type of collective, anti-government activity is often treated as the primary threat, based on the assumption that the most serious threat to a leader is the threat to his or her tenure (Moore, 1998, 2000; Carey, 2006; Francisco, 1996; Davenport, 1995).

Yet repression is not the only available option - leaders can also accommodate protesters' demands. Concessions are a relatively common strategic response. In a study of seven Latin American countries, Franklin (2009) finds that about 20\% of protest events from 19811995 were met with accommodation, in comparison to the $30 \%$ of events that were met with repression. The remaining $50 \%$ of events were tolerated, or ignored. Carey (2006), in a study of nine African and Latin American countries over a similar time period, finds 
that while the magnitude of repression tends to be higher, there was also substantial state accommodation. ${ }^{2}$ Concessions were similarly given during the 1994-2003 Zapatista protests in Mexico (Inclán, 2009) as well as the Iranian Revolution (Rasler, 1996).

Beyond being a common tool of leaders, there is also a wide range of potential concessions leaders can give. The Arab Spring provides a good example on the range of available concessions. It was fairly common to see governor fired, cabinets reshuffled, promises of reform, and the creation of various committees. Some states made economic concessions, such as lowering the costs of foodstuffs or giving financial benefits to students. There were fewer cases of scheduling elections, drafting new constitutions, or lifting emergency law. This displays the range of accommodations available, which varied in terms of their magnitude and relevance to protester demands.

\section{Treaty commitments as a policy concession}

In order to consider the likelihood of treaty commitments within the context of dissent, it is important to establish that treaty commitments can be a relevant concession. Improving human rights is a common demand of protesters. The Social Conflict Analysis Database, which codes protest events including demonstrations, strikes, and riots lists human rights or democracy as the most common issue mentioned by demonstrators, occurring in about $20 \%$ of all events across Africa from 1990-2010 (Salehyan et al., 2012). ${ }^{3}$ Democratization and better respect for human rights are a very common requests from demonstrators, and Salehyan et al. (2012) group these two goals together - democratization and greater respect for rights - reflecting their interconnected nature.

Committing to human rights treaties represents a potential response to these demands, as it can act as a signal of the government's intent to improve their human rights practices. While treaty commitments may not be particularly substantial, many concessions offered by

\footnotetext{
${ }^{2}$ Carey (2006) uses data that is weighted by the magnitude of the conflict or cooperative action. The cited relationship is then about the average level of cooperation or conflict by the government.

${ }^{3}$ The next most common issue is economy/jobs, at $16 \%$, followed by domestic war/violence/terrorism at $11 \%$, and ethnic discrimination at $9 \%$.
} 
the government are not, such as establishing committees to examine human rights abuses. Risse \& Sikkink (1999) describe these as 'tactical concessions,' commonly made by governments in attempt to signal that the regime supports and recognizes these rights, but require little by way of policy change.

Beyond generally demanding better human rights records, groups also specifically campaign for the ratification of human rights treaties. It is well known that treaty ratification is a common demand of international organizations and international nongovernmental organizations (Murdie \& Davis, 2012). These pressures also exist at the domestic level. Domestic human rights organizations (HROs) work to pressure their government into treaty ratification as one facet of a campaign to improve human rights. For example, Smith (2013) argues that in the US and UK a number of domestic groups advocated for ratification/accession of the Genocide Convention. In the 1980s, Chile's nonviolent movement pressured Pinochet to join the Convention Against Torture (CAT), and as a current example, domestic groups continue to pressure China to ratify the International Covenant on Civil and Political Rights (ICCPR). Further, Hathaway (2007) finds that states with large numbers of HROs are more likely to ratify the CAT and its optional protocols, indicating that these domestic pressures can promote ratification.

[Table 1 about here.]

This indicates that the pressure to improve human rights records and join treaties is not only a top-down process; there are also domestic pressures to ratify. In particular, I focus on signing and ratifying the UN's core human rights treaties that are currently in force. These treaties are listed in Table I, and are each legally binding, global instruments that address what can be thought of as the core values of the international community. This includes protecting different classes of rights, including economic and social rights, political and civil rights, and protection against the use of torture and disappearances. They also protect certain groups against discrimination, including women, children, ethnic groups, migrant workers, and people with disabilities. The promotion of these rights and the protection of 
marginalized or vulnerable groups are foundational democratic principles that can speak to demands for improved human rights practices and democratic governance.

In the next section, the existing literature on human rights treaty ratification is considered, which is used as a point of departure to explore how the context of dissent influences the government's cost-calculation regarding treaty commitments.

\section{The puzzle of ratification}

A number of studies have considered the puzzle of why states join human rights treaties. In committing to a human rights treaty, states incur sovereignty costs as leaders shift the power to judge the treatment of their citizens to outside actors (Moravcsik, 2000). At the same time, the benefits that typically accompany the ratification of an international treaty gained through reciprocity are not present. One set of explanations focuses on the 'logic of appropriateness,' or the power of norms as an influence on state decisions. Within these perspectives, it is not material interests that drive states' preferences, but normative commitments (Hathaway, 2003).

A second approach focuses on the costs and benefits that arise from commitments, arguing that while norms may be a powerful force, cost calculations may be able to better explain the timing of ratification (Cole, 2005). First, ratification acts as an expression of a state's values and intentions, and thus joining a treaty carries some degree of 'expressive benefits' (Hathaway, 2002). Ratification can also afford a state 'social camouflage' if states ratify relative to similar countries in their geographical region, removing the spotlight from their human rights practices (Simmons, 2009). Potential costs include the costs of compliance for countries that must work to bring their own institutions and practices into line with the treaty (Goodliffe \& Hawkins, 2006), which may be higher in some settings, such as common law systems (Simmons, 2009). There can also be a loss of flexibility, especially important 
in responses to domestic threats, as commitments to human rights treaties may constrain a state from using repression in the future (Goodliffe \& Hawkins, 2006).

Within this framework of costs and benefits, two approaches focus specifically on domestic pressures. The first is democratic 'lock-in' (Moravcsik, 2000; Mansfield \& Pevehouse, 2006, 2008; Hafner-Burton, Mansfield \& Pevehouse, 2015), by which governments ratify human rights treaties in order to reduce political uncertainty in the future and protect the government against non-democratic threats. In other words, leaders may use the costs of ratification to their advantage, to ensure future, democratic practices and avoid backsliding into authoritarianism. Vreeland (2008) also examines domestic pressures for ratification, addressing the puzzle of why dictators who torture the most are also the most likely to join the Convention Against Torture. He argues that in multiparty dictatorships, alternative points of view are allowed to some extent, which can increase the use of torture as some individuals go 'too far'; however, multiple political parties can also pressure the regime into granting concessions in turn for their support of the regime, one of which is committing to the CAT.

These two arguments, on democratic lock-in and opposition parties in autocracies, are undoubtedly important to advance our understanding of how domestic pressures and motivations influence treaty ratification. Both approaches primarily focus on elites, whether elite motivations to tie the hands of the government or pressure from opposition political parties. To expand this line of inquiry, I examine the role of bottom-up pressure on treaty commitments.

\section{Domestic dissent and ratification as accommodation}

Anti-government movements present unique challenges to leaders. This section draws from the literatures on both protest and treaty ratification to develop expectations on granting treaty commitments during anti-government dissent. 


\section{The costs and benefits of concessions}

In comparison to repression and tolerance, accommodation is a relatively costly response (Franklin, 2009). While all three strategies can encourage higher levels of protest in the long-term, granting concessions arguably produces the highest costs in the short run.

Tolerance in particular has low immediate costs. Perhaps the greatest risk with tolerance is that it can legitimize a movement and signal to protesters that they are unlikely to be repressed, encouraging greater participation in the campaign. Repression likewise has low immediate costs, primarily the material costs of carrying out the coercion. However, coercion also has the potential to be costly in the long term given its backlash potential. Repression may lead to "widespread outrage, causing individuals to place greater value in opposing the government,' increasing support in the anti-government movement and encouraging greater dissent (Franklin, 2009: 702).

Like tolerance and repression, concessions may also lead to the growth of the movement. Granting concessions can carry the same legitimizing costs as tolerance, while previous research has found that accommodations can encourage future protest (e.g., Rasler, 1996). The primary difference is that accommodation carries higher short-term costs, as concessions require a change in governmental policy. While all three strategies can lead to the growth of a protest movement, accommodation is the only response that requires that movement from the status quo, as well.

An important question is when this strategy will be adopted in spite of those costs. I argue that accommodation will be used when tolerance and repression become unattractive options. In particular, large and nonviolent movements can encourage leaders to look towards accommodation, as these movements are too large to ignore yet risky to repress.

\section{Large, nonviolent campaigns}

It is first expected that large-scale protest campaigns will be more likely to elicit a government response, whether repression or concessions (Franklin, 2009). Movements that are relatively 
large will pose a greater threat to the government, and as a result there is likely to be a greater focused placed on short-term benefits of ending the threat. This renders tolerance a less attractive strategy. Some have found that participation increases the likelihood of repression (Lichbach \& Gurr, 1981), although others have argued that greater levels of participation may discourage repression given the difficulty in applying coercion fully (Franklin, 2009). While there is disagreement about the use of repression in the face of large-scale movements, the use of nonviolence is expected to discourage its use.

A number of studies demonstrate the danger of heavily repressing nonviolent movements, due to the increased likelihood of backlash (e.g., Davenport, 1995; Stephan \& Chenoweth, 2008; Martin, 2007). In the face of a violent threat, repression is more likely to be viewed as a legitimate action of the state, as violence can pose a serious threat to the state and the safety of its citizens (Davenport, 1995). Conversely, repressing a nonviolent movement is less likely to be seen as legitimate as demonstrators do not pose the same threat. Coercion is more likely to produce a backlash effect and ultimately strengthen the movement through encouraging individuals to join the movement, the defection of state actors from the security forces or civil service, or the attention of external actors, who may sanction the government or lend aid to the movement (Stephan \& Chenoweth, 2008). It is thus expected that large, nonviolent movements are less likely to be repressed, as repression becomes a risky and less attractive strategy. ${ }^{4}$

Large, nonviolent campaigns are then difficult to ignore, as leaders attempt to end the threat in the short-term, while repression is risky given the use of nonviolence. Under these conditions, leaders may turn to concessions in attempt to pacify demonstrators.

\footnotetext{
${ }^{4}$ This expectation about the tradeoffs between repression and other strategies in the context of nonviolent movements is tested empirically using the NAVCO 2.0 data, presented in Table V. Results suggest that repression becomes less likely as nonviolent movements grow in size.
} 


\section{Maximalist goals}

While large, nonviolent campaigns make concessions a more attractive strategic response in general, pro-democracy goals are expected to increase the chances of receiving commitment to human rights treaties in particular. First, it is important to note that the expectation that pro-democracy goals will produce treaty commitments runs counter to findings in the literature that limited demands are likely to be met with accommodation (Franklin, 2009; O’Keefe \& Schumaker, 1983; Schumaker, 1975). In previous studies, extensive demands include political change (Bratton \& Walle, 1992); equal rights, such as civil liberties (Schumaker, 1975); and 'universalist' concessions that affect the entire population rather than a limited group (Franklin, 2009), including elections (Kowalewski \& Schumaker, 1981). These types of demands are quite similar to what would be expected from a group that desires human rights reform or democratization more generally.

Indeed, extreme demands like regime change are not expected to be accommodated if it can be avoided - leaders will not simply abdicate when groups demand their ouster. However, maximalist goals can produce commitments to human rights treaties specifically because they have significant demands. The argument is not that these previous studies and their findings are incorrect; rather, the focus is on particular type of concession - treaty commitmentswhich requires a different starting point for considering when accommodation is likely. It is not expected that governments will offer more to dissenters than they demand. If the goal of a demonstration is to lower the cost of fuel, there is little reason to offer promises of better human rights. Demands for human rights and democracy are maximalist, and treaty commitments are a step in this direction.

In addition, treaties are an attractive option because they address these goals at a low-cost (e.g., Hathaway, 2002; Hafner-Burton, Tsutsui \& Meyer, 2008; Hafner-Burton \& Tsutsui, 2005; Cole, 2005). States can first choose to sign a human rights treaty, which is not legally binding but rather expresses willingness to join. In some countries, signature may be taken as a purely 'symbolic gesture' in which states declare their support of a treaty without 
making any real commitment to comply (Vreeland, 2008). In others, ratification is a difficult process that requires multiple power holders to approve of the treaty. In the United States for example, the executive branch may negotiate and draw treaties, but may only ratify with the 'advice and consent' of the Senate. Thus some countries may be required to sign before ratification becomes possible.

States can also ratify the treaty, at which point it is legally binding. The cost of compliance can be high, especially if domestic practices diverge from the stipulations of the treaty, but only if a state is forced to comply with the treaty or otherwise makes an effort to do so (Hathaway, 2003). Human rights treaties have weak enforcement mechanisms to monitor or enforce, which renders treaty commitments a 'relatively costless step' (Hathaway, 2002). For example, the ICESCR requires states to submit a report two years after ratification, and every five years thereafter. The Committee on Economic, Social and Cultural Rights considers and responds to these treaties, but has little ability to ensure reports are submitted, while even cursory reports technically fulfill obligations (Cole, 2005).

\section{Pinochet, Chile, and the CAT}

Chile's ratification of the CAT illustrates how nonviolent, pro-democracy movements can pressure the regime to provide concessions, specifically commitments to human rights treaties. Augusto Pinochet came to power in 1973 after overthrowing Salvador Allende in a coup d'état, suspending Chile's long history with democracy to establish a military dictatorship (Ropp \& Sikkink, 1999). Opponents to Pinochet's repressive tactics emerged early in his rule, and arguably established the first human rights organizations as both domestic and transnational actors mobilized against the government (Ropp \& Sikkink, 1999). After a decade of limited success against the regime, in 1983 union leaders met and planned the first major protest against Pinochet. The protest was repressed, with 600 arrested and several killed (Ackerman \& DuVall, 2000). This backfired and led to the growth of the movement, which began holding monthly protest events. The government adopted a mixed strategy following 
the movement's growth, repressing protesters despite the backlash, while also giving limited concessions, such as allowing exiles to return, slightly expanding freedom of the press, and granting permission to hold demonstrations. The opposition movement took advantage of these opportunities, and mobilized hundreds of thousands of people in 1983 and 1984 .

A transition to democracy and improved respect for human rights were central goals of the movement. In 1985, opposition groups came together to sign the National Accord for Full Transition to Democracy (Acuerda Nacional), while the movement's slogan 'We have clean hands' (Tenemos las manos limpias) was accompanied by people holding up their hands with their palms held outward as a symbol of their peaceful tactics, which stood in stark contrast to those of the regime (Ackerman \& DuVall, 2000: 291). In line with goals of better human rights practices, after the adoption of the CAT by the UN, calls were made within Chile for the regime to join the convention:

In June 1985, the Sebastian Acevedo Movement Against Torture held 'hit-andrun' demonstrations with a massive banner that read, 'Why doesn't Chile sign the international Convention Against Torture?' The demonstrators demanded that government authorities explain why Chile had not signed the CAT, which radio commentators announced allows "neither exceptions nor orders ... [to] justify torture' (Simmons, 2009: 290).

The junta would eventually give way under the pressure, and signed the CAT in 1987 and ratified the following year. ${ }^{5}$

In sum, treaty commitments are expected in the face of protest campaigns that are nonviolent, large-scale, and that have pro-democracy demands. These movements represent a threat that is too serious to ignore, yet risky to repress, and maximalist goals are difficult to address in a low-cost way. This can be seen in the case of Chile, where although repression continued to be used, it backfired against nonviolent tactics, and the government

\footnotetext{
${ }^{5}$ Chile likewise has a special connection to the CAT, in that some argue Chile's gross use of torture inspired the creation of the treaty. Pinochet himself would be the first head of state to be indicted for human rights violations, in accordance with the CAT's provisions for universal jurisdiction.
} 
turned towards limited concessions as the movement gained strength. Treaty commitments, with their limited enforcement mechanisms, can serve as a relatively costless option to offer protesters. Expectations can be summarized with the following hypotheses:

$H_{1}$ : Pro-democracy, nonviolent campaigns increase the likelihood of signing and ratifying the core human rights treaties.

$\mathrm{H}_{2}$ : As the size of pro-democracy, nonviolent campaigns increases, the likelihood of signing and ratifying the core human rights treaties also increases.

\section{Research design}

\section{Dependent variable and model}

Pooled models In order to test expectations on the effect of nonviolent movements on treaty commitments, two sets of models were conducted. First, following Hafner-Burton, Tsutsui \& Meyer (2008), two dichotomous dependent variables were generated. The first takes on a value of 1 if a country signed one or more treaties in a given year, and is 0 otherwise. The second takes on a value of 1 if a country ratified one or more treaties in a given year. Logistic regression is used with robust standard errors clustered at the country level. The time period covered by these models is 1965-2006, the year the ICERD opened for signature until the coverage ends of the NAVCO data.

Given the construction of these dependent variables, there are strong time trends that reflect the release date of treaties that also need to be modeled. It is common to have many countries sign treaties in the first few years after a treaty has opened, with declining frequency over time. This leads to clustering of the dependent variable in specific years. To account for these dynamics, a time counter is included in the model that resets when a new

treaty is released. For example, the time counter starts at 1 in 1965 when the ICERD opened for signature, resets at 1 in 1966 since the ICESCR and ICCPR were opened for signature, 
then counts up until 1979, when it resets once more due to the release of CEDAW, and so on. There are other ways in which the time trends can be modeled; this specification consistently captured a large percentage of the variance and provides a fairly intuitive approach. ${ }^{6}$

Individual treaty models A second set of models was also conducted for each individual treaty. For each treaty, one model was run to capture the effect of nonviolent movements on the time to treaty signature, and a second model to capture the effect of movements on the time to ratification. Altogether, 28 different models were conducted to capture the effects of the two main independent variables, nonviolent movements and nonviolent movement size, on both treaty signature and ratification. ${ }^{7}$ Rather than present the full results for each of these unique models, coefficient plots of the primary independent variables with confidence intervals are presented in the Results section. ${ }^{8}$

For the individual models, the first year included in the model is the first year that treaty was opened for signature. For the ICCPR, for example, the data start in 1966 since the treaty was opened for signature in 1966. For reference, Table I lists the date each treaty was opened for signature. For the ratification models, countries drop out once they have ratified a treaty. For the signature models, countries drop out once they sign a treaty. Countries also drop out of the signature model if the treaty is ratified without first signing, as a country can no longer sign a treaty that has already been ratified. Cox proportional hazards models are used to individually test the treaties, with robust standard errors clustered at the country level. ${ }^{9}$

\footnotetext{
${ }^{6}$ Additional models were also run with different specifications. The Online Appendix includes results using cubic splines, with very similar results.

${ }^{7}$ Models could only be constructed for seven of the nine human rights treaties due to data limitations. The NAVCO data run until 2006, and two of the treaties, the CRPD and CPED, first opened for signature in 2006. Models were constructed for each of the remaining seven treaties.

${ }^{8}$ Full results can be found in the Online Appendix.

${ }^{9}$ The Cox model is very flexible as it makes no assumptions about the underlying hazard rate, which is why it was used here. Weibull models, along with additional specifications, were also run following Vreeland (2008). Results were nearly identical.
} 


\section{Primary independent variables}

The two primary independent variables are taken from the Nonviolent and Violent Campaigns and Outcomes (NAVCO) data project, version 2.0 (Chenoweth \& Lewis, 2013). The NAVCO data provide campaign-year data on both violent and nonviolent insurrections from 1945-2006. A campaign is defined as 'a series of observable, continuous, purposive mass tactics or events in pursuit of a political objective' (Chenoweth \& Lewis, 2013: 416). The events can be either violent or nonviolent, and campaigns are coded based on the primary tactic used in a given year to determine whether it was a violent or nonviolent campaign. To be included in the data, campaigns must have at least 1,000 observable members at some point in its history, along with an organization of some type that links events over time. In addition, NAVCO requires campaigns to have maximalist goals of either replacing the government, achieving self-determination, or expelling foreign occupations. In order to test the hypotheses, only the subset of these campaigns that were pro-democracy movements are included in the analysis. ${ }^{10}$ Nonviolent, pro-democracy movements occur in all regime types. In the data under study, 50 non-democracies experienced a nonviolent movement.

Taken together, the campaigns included in the analysis fit the type of protest movements discussed above. They have pro-democracy goals, are nonviolent, and require a relatively large membership. The first measure indicates whether there was a nonviolent movement in a given year. ${ }^{11}$ A second measure is included on the size of the campaign in terms of membership, which captures the size of the largest active nonviolent group in a given year. This measure is coded 0 for no campaign, 1 for less than 9,999 participants, 2 for 10,00099,999 participants, 3 for 100,000-999,999 participants, and 4 for 1,000,000 participants or more.

\footnotetext{
${ }^{10}$ The campaign goals were coded by the author using material from NAVCO, news reports, and other primary sources. The majority of movements that fought to replace the central government were also prodemocracy movements. Movements to replace the central government were also tested in addition to testing only pro-democracy movements, and the results were nearly identical.

${ }^{11}$ In many countries there were multiple ongoing movements in the same year. Tests were run using counts of nonviolent campaigns, and results were nearly identical.
} 
It is expected that the presence and size of a nonviolent campaign will increase the likelihood of treaty commitments. In the time frame under study, there are a total of 35 cases of ratification during a nonviolent movement and 29 cases of signature during a nonviolent movement. A total of 34 countries either signed or ratified a human rights treaty during a nonviolent movement.

\section{Additional independent variables}

In addition to the measures on nonviolent movements, two measures of violent campaigns are included, also from NAVCO. One indicator was constructed for whether there is a violent movement in a given year, and a second for the size of that movement. Only violent campaigns against the central government are included. The size measure has the same scale for both the violent and nonviolent campaigns. ${ }^{12}$

Data on a country's human rights record is also included from Fariss (2014). This is a measure of latent repression constructed using a number of both events-based and standardsbased data sources that measure physical integrity violations, such as illegal imprisonment, torture, killing, and genocide (e.g. Cingranelli \& Richards, 1999; Gibney, Cornett \& Wood, 2010; Hathaway, 2002). This measure of repression takes into account the changing standards of accountability used by human rights monitoring bodies over time (e.g., Amnesty International and the US State Department) to produce an unbiased estimate of repression. This measure is continuous, with negative values indicating worse human rights practices and positive values indicating better human rights records.

A measure of common law systems is included to capture their relatively high compliance costs. This measure is taken from the Quality of Government data, and is coded 1 for countries with a common law system and 0 otherwise (Teorell et al., 2013). A measure of regime type is included from the Polity IV data (Marshall \& Jaggers, 2006). The 21 point scale, with -10 indicating an autocracy and 10 a democracy, is included. In addition, a measure

\footnotetext{
${ }^{12}$ Each movement is coded as either nonviolent or violent in a given year. The presence of multiple campaigns makes it possible to have both a violent and nonviolent movement in the same year.
} 
of new democracies is included to account for democratic lock-in arguments (e.g., Moravcsik, 2000). This measure is also constructed using the Polity IV data. It is a dichotomous variable, with 1 indicating that the state is newly independent and also democratic, or has recently democratized and is also democratic. A country is considered democratic if it is a 7 or greater on the Polity scale, and is considered to have transitioned if there was any forward movement on the scale. The measure is coded for five years after independence or democratization.

A measure that captures the number of treaties that a given country has either signed or ratified is included in the pooled models. In the signature model, the indicator is a running sum of the number of treaties a country has signed. This is included as some countries may not typically sign treaties and only ratify, while others may sign treaties often. In the pooled ratification model, this variable is a running sum of the number of treaties a country has ratified.

Finally, a measure is included only in the individual treaty models that captures regional ratification rates of the specific treaties, and is the percentage of countries that have ratified the treaty under study, by year and by region. For example, in the models for the ICCPR, the measure reflects the percentage of countries in a given region that have ratified the ICCPR in a given year. Summary statistics can be found in Table II. All independent variables are lagged one year in both the pooled and individual models.

[Table 2 about here.]

\section{Results}

\section{Pooled models}

Results of the pooled models are presented in Table III and are generally supportive of expectations. Model 1 presents results for the presence of a nonviolent campaign on the signature

of human rights treaties (Hypothesis 1), and the presence of a nonviolent campaign increases 
the likelihood of signing and is statistically significant. Countries with an ongoing nonviolent movement are about 1.6 times more likely to sign human rights treaties than countries without a nonviolent movement. By contrast, violent movements lead to a statistically significant decrease in the chances of treaty signature. Countries with an ongoing violent movement are 1.5 times less likely to sign.

[Table 3 about here.]

A similar dynamic can be found in Model 3, which tests the effect of nonviolent movements on treaty ratification. Nonviolent movements lead to a statistically significant increase in the chances of ratification. A country with a nonviolent movement is about 1.8 times more likely to ratify a treaty than a country without a movement. Violent movements have a positive effect on ratification as well, but this finding is statistically insignificant.

Moving to Hypothesis 2, both Models 2 and 4 show support for the expectation that the size of a nonviolent movement increases the chances of treaty commitments. For treaty signature and ratification, as a country moves between categories, it becomes about 1.2 times more likely to commit to a human rights treaty. Results are statistically significant for the ratification model, and level of significance is just outside of conventional levels, at $p=0.054$, for the model on signatures. Violent campaign size shows similar trends as well, with a statistically significant, negative effect on treaty signature and a weakly positive, but statistically insignificant, effect on ratification.

The remaining variables largely perform as expected, with some interesting distinctions between signing and ratification. Respect for human rights does not reach statistical significance in either model, but is weakly negative for signature and positive for ratification. This may suggest that more egregious violators are more likely to sign, and those who respect human rights more likely to ratify. These results do not differentiate between regime type, and thus may reflect noise of unaccounted for conditional relationships (Vreeland, 2008).

Common law systems lead to a statistically significant decrease in the chances of signing or ratifying human rights treaties, as expected (Simmons, 2009). They are about 30\% 
less likely to sign and about $15 \%$ less likely to ratify. These countries are likely to face greater compliance costs, as the judiciary has greater power to interpret and apply the law. More democratic countries are more likely to sign and ratify to human rights treaties. This relationship only reaches statistical significance, however, for treaty signature. As countries become more democratic by an increase of one point on the Polity scale, they are about $5 \%$ more likely to sign a treaty and about $1 \%$ more likely to ratify. New democracies, however, do not appear to be any more likely to ratify treaties, and if anything are less likely to sign treaties. This may also point to different motivations for treaty signature versus ratification.

The indicator for the number of treaties that have been signed or ratified shows interesting differences between models, as well. The number of treaties signed is positive and statistically significant for Model 2, and relatively close to statistical significance in Model 1. This suggests that countries are more likely to sign treaties if they have signed in the past. This reflects the nature of signature, which is not done by every country. Conversely, the ratification measure is negative and statistically significant. This may reflect the pattern of treaty ratification, where countries that quickly ratify 'run out of options' and thus have fewer treaties available to join.

Finally, the time counter indicator, which measures the number of years since the last treaty was released, is negative and statistically significant as expected. Many countries sign and ratify treaties in the first few years after release, and the number of commitments decrease as time passes. This is reflected in this indicator, which suggests that signature in particular is influenced by this time dynamic.

\section{Individual treaties}

Results for the individual Cox models are presented in Figures 1 and 2, which are coefficient plots of the independent variables of interest, nonviolent movements and the size of nonviolent movements. ${ }^{13}$ These figures show coefficients and $90 \%$ confidence intervals. ${ }^{14}$

\footnotetext{
${ }^{13}$ Full results are available in the online appendix

${ }^{14}$ The number of subjects ranges from $157-170$ and the number of failures from $25-153$.
} 
[Figure 1 about here.]

[Figure 2 about here.]

There are some very interesting differences between the signature and ratification models. First, all treaties display a positive relationship between nonviolent movements and signature, as shown in Figure 1. This holds both for the presence of a campaign and the size of a campaign. The majority of these relationships are also statistically significant. Only the results from the ICERD and CEDAW are statistically insignificant across both models; the IMWC is statistically significant only for the presence of a movement and not size.

Figure 2 shows results for the ratification models, which have a different overall pattern. Most of the models show a positive relationship between nonviolent movements and treaty ratification, as expected, but this is not the case with all treaties. For the ICERD and CEDAW the direction of the relationship is negative. ${ }^{15}$ Additionally, none of the nonviolent protest coefficients are statistically significant with the exception of a single model, the signature of the IMWC. While most models show a positive relationship between nonviolent movements and ratification, the results are not statistically significant.

Why are the individual results statistically insignificant for the ratification data? Ultimately, there are more costs to treaty ratification. Treaties are legally binding, and can encourage domestic or international actors to push for change, and leaders may be reluctant to join a particular treaty in the face of bottom-up pressure. The individual treaty models test whether a state is willing to ratify a specific treaty, and these results may reflect the preferences of governments that are selective about which rights they are willing to endorse. It may only be that ratification occurs if leaders have options, and can choose to join one treaty over another, that accession in the face of protest occurs. In contrast, signature requires no formal commitments, suggesting that leaders may sign any of the treaties if the domestic environment calls for a concession even if there is reluctance to eventually ratify.

\footnotetext{
${ }^{15}$ The ICERD results are excluded from the campaign size figure because it was close to a perfect negative predictor of ratification and could not be reasonably graphed, as it skewed the graph far to the left.
} 


\section{Extensions}

Two additional extension are tested. The first is a robustness check for whether these results are simply a product of successful campaigns. The second provides a test of an important assumption made in the article, which is that repression becomes less likely as movements grow in size.

Successful movements? A possible explanation for the findings is that treaty commitments are the result of successful nonviolent campaigns. In other words, it may only be that after a nonviolent campaign achieves democratic regime change that treaties are signed or ratified. If so, these results may be a reflection of democratic lock-in, after all. The statistical insignificance of this measure in the primary results may be an issue of operationalization rather than theoretical explanation. To test this, an additional indicator from the NAVCO data is constructed for whether a pro-democracy campaign was successful, coded 1 if regime change was achieved. Movements that failed to achieve regime change are also coded and included in Models 2 and 4.

\section{[Table 4 about here.]}

Table IV shows that campaign success does not reach conventional levels of statistical significance in the signature model, and in Model 2 it is actually the movements that have not been successful that lead to a statistically significant increase in the chances of treaty signature. By contrast, successful movements do tend to produce treaty ratification, which lends support for the democratic lock-in arguments. In Model 4, both forms of nonviolent movements, those that have reached full success and those that have not, are linked to success. Remaining indicators are very similar to the primary results in Table III. This produces another interesting layer in terms of the differences between signature and ratification, suggesting that ratification of treaties is a more complex process than is signature. Ratification appears to be likely when there is choice, rather than for a specific treaty, and it is more likely to be linked to movement success. 
Repressing nonviolence Table $\mathrm{V}$ shows results that test the assumption that repression becomes riskier and less attractive as movements grow in size. It is expected that larger, nonviolent movements are less likely to be repressed. This model was conducted using the NAVCO data. The dependent variable is the NAVCO repression measure, which codes the degree to which nonviolent movements were repressed. Higher values reflect higher levels of repression, and about $60 \%$ of nonviolent campaign years were met with either moderate or extreme levels of repression. ${ }^{16}$ The same campaign size variable used in the main analysis is the primary independent variable. Additional independent variables include a radical flank, the goal of regime change, if the regime has external support from other states, and if the movement has external support from INGOs. ${ }^{17}$ An ordered logistic regression, with robust standard errors clustered at the country level, is used to test this relationship. ${ }^{18}$

[Table 5 about here.]

Results lend empirical support to the assumption that larger campaigns are less likely to be repressed. Importantly, this is not to say that the government abandons the strategy of repression altogether. Rather, leaders may look towards other strategies especially as movements grow in size. This is expected both due to backlash potential of nonviolence (e.g., Chenoweth \& Stephan, 2011) and the difficulty in fully repressing very large movements (Franklin, 2009).

\section{Discussion and conclusion}

While repression is an expected response to anti-government dissent, leaders can also accommodate protesters. The conditions under which policy concessions are likely has been less

\footnotetext{
${ }^{16}$ This measure was collapsed into three categories: none, mild, or extreme levels of repression based on tests run using the data. The Online Appendix includes a further exploration of this relationship.

${ }^{17}$ The NAVCO codebook includes more detailed information on these measures and their coding (Chenoweth \& Lewis, 2013).

${ }^{18}$ The parallel regression assumption was tested for both models using an approximate likelihood ratio test and a Brant test, and neither could reject the parallel regression assumption.
} 
well studied, however. Here, treaty commitments are conceptualized as a policy concession that the government can give demonstrators, allowing for insights from the treaty ratification literature to shed light on the question of government accommodation. I argue that large, nonviolent, and pro-democracy campaigns increase the likelihood of commitments to the UN's core human rights treaties. These campaigns are too threatening to ignore yet costly to repress. Their pro-democracy goals demand larger pro-democracy and human rights concessions, and treaty commitments provide a low-cost option. Expectations were tested using commitments to the UN treaties and the NAVCO 2.0 data, and results were generally supportive. However, results showed interesting differences between signature and ratification; while treaty signature is robust to a number of different model specifications, ratification was not. Nonviolent movements were not statistically significant in models of the individual treaties, while ratification was also tied to movement success.

The results produce implications for both research and policy. First, there seem to be interesting and potentially important differences between signature and ratification. There is variation in whether states sign a treaty first or only ratify, and in the time between signature and accession. There are likewise many cases of signature without ratification. This is an area that can be further explored to examine whether signature is more prone to political maneuvering given its low costs, or if this variation is a result of domestic barriers in countries who take human rights seriously (e.g., Neumayer, 2005).

In terms of responses to anti-government dissent, results suggest that leaders are, as expected, conservative and rooted to the status quo. Signing a treaty is a particularly low-cost concession, and while a signature may affect the beliefs and behavior of domestic actors, and perhaps encourage attention from international actors, it does not carry the same weight as ratification. This propensity to give low-cost concessions is something that can be further explored to examine if the majority of concessions given are low-cost, and when more signification accommodations are given. There are also important questions about the 
effect that both high and low-cost concessions have on the trajectory of protest movements that can be further explored.

This research also produces policy implications. First, nonviolent movements are more likely to gain these concessions as compared to violent campaigns, which had no influence on the likelihood of treaty ratification and lead to a statistically significant decrease in the chances of treaty signature. This may reflect the government's unwillingness to compromise given violence, and these findings complement existing studies on nonviolence well (e.g., Chenoweth \& Stephan, 2011). However, a partial success implies a note of caution. While partial successes can be important, and may become building blocks for change, the gains made should be carefully considered. Signing a human rights treaty does not carry the same implications as does ratification; likewise other concessions given may be less significant than they may otherwise appear. This may be particularly important after a large-scale campaign ends, as attention from the international community and media turn elsewhere.

\section{Replication data}

The dataset, codebook, and do-files for the empirical analysis in this article, along with the online appendix, are available at https://www.prio.org/jpr/datasets/. All analyses were conducted using Stata 12.

\section{Acknowledgements}

Thanks to Gary Goertz, three anonymous reviews, and Associate Editor Sabine Carey for their very insightful comments and suggestions. This paper was presented at the International Studies Association annual meeting in 2010; thanks in particular to Michael Colaresi for his useful comments. 


\section{References}

Ackerman, Peter \& Jack DuVall (2000) A Force More Powerful: A Century of Nonviolent Conflict. London: Palgrave Macmillan.

Bratton, Michael \& Nicolas van de Walle (1992) Popular protest and political reform in Africa. Comparative Politics 24(4): 419-442.

Carey, Sabine C (2006) The dynamic relationship between protest and repression. Political Research Quarterly 59(1): 1-11.

Chenoweth, Erica \& Orion A Lewis (2013) Unpacking nonviolent campaigns: Introducing the NAVCO 2.0 dataset. Journal of Peace Research 50(3): 415-423.

Chenoweth, Erica \& Maria Stephan (2011) Why Civil Resistance Works: The Strategic Logic of Nonviolent Conflict. New York: Columbia University Press.

Cingranelli, David L \& David L Richards (1999) Measuring the level, pattern, and sequence of government respect for physical integrity rights. International Studies Quarterly 43(2): $407-417$.

Cole, Wade M (2005) Sovereignty relinquished? Explaining commitment to the international human rights covenants, 1966-1999. American Sociological Review 70(3): 472-495.

Davenport, Christian (1995) Multi-dimensional threat perception and state repression: An inquiry into why states apply negative sanctions. American Journal of Political Science 39(3): $683-713$.

Davenport, Christian (2007) State repression and political order. Annual Review of Political Science 10(1): 1-23.

Fariss, Christopher J (2014) Respect for human rights has improved over time: Modeling the changing standard of accountability. American Political Science Review 108(02): $297-318$.

Francisco, Ronald A (1996) Coercion and protest: An empirical test in two democratic states. American Journal of Political Science 40(4): 1179-1204.

Franklin, James C (2009) Contentious challenges and government responses in Latin America. Political Research Quarterly 62(4): 700-714.

Goodliffe, Jay \& Darren G Hawkins (2006) Explaining commitment: States and the Convention Against Torture. The Journal of Politics 68(2): 358-371.

Gurr, Ted R (1986) The political origins of state violence and terror: A theoretical analysis. In: Michael Stohl \& George Lopez (eds) Governmental Violence and Repression: An Agenda for Research. New York: Greenwood, 45-72. 
Hafner-Burton, Emilie M; Edward D Mansfield \& Jon C Pevehouse (2015) Human rights institutions, sovereignty costs and democratization. British Journal of Political Science 45(01): 1-27.

Hafner-Burton, Emilie M \& Kiyoteru Tsutsui (2005) Human rights in a globalizing world: The paradox of empty promises. The American Journal of Sociology 110(5): 1373-1411.

Hafner-Burton, Emilie M; Kiyoteru Tsutsui \& John W Meyer (2008) International human rights law and the politics of legitimation repressive states and human rights treaties. International Sociology 23(1): 115-141.

Hathaway, Oona A (2002) Do human rights treaties make a difference? Yale Law Journal 111(8): 1935-2042.

Hathaway, Oona A (2003) The cost of commitment. Stanford Law Review 55(5): 1821-1862.

Hathaway, Oona A (2007) Why do countries commit to human rights treaties? Journal of Conflict Resolution 51(4): 588-621.

Inclán, María L (2009) Repressive threats, procedural concessions, and the Zapatista cycle of protests, 19942003. Journal of Conflict Resolution 53(5): 794-819.

Kowalewski, David \& Paul Schumaker (1981) Protest outcomes in the Soviet Union. The Sociological Quarterly 22(1): 57-68.

Lichbach, Mark I \& Ted R Gurr (1981) The conflict process: A formal model. The Journal of Conflict Resolution 25(1): 3-29.

Mansfield, Edward D \& Jon C Pevehouse (2006) Democratization and international organizations. International Organization 60(01): 137-167.

Mansfield, Edward D \& Jon C Pevehouse (2008) Democratization and the varieties of international organizations. Journal of Conflict Resolution 52(2): 269-294.

Marshall, Monty G \& Keith Jaggers (2006) Polity IV Project: Political regime characteristics and transitions, 1800-2004: Dataset users' manual. Polity IV Project. Center for Global Policy School of Public Policy, George Mason University.

Martin, Brian (2007) Justice Ignited: The Dynamics of Backfire. Lanham, MD: Rowman \& Littlefield.

Moore, Will H (1998) Repression and dissent: Substitution, context, and timing. American Journal of Political Science 42(3): 851-873.

Moore, Will H (2000) The repression of dissent: A substitution model of government coercion. The Journal of Conflict Resolution 44(1): 107-127.

Moravcsik, Andrew (2000) The origins of human rights regimes: Democratic delegation in postwar Europe. International Organization 54(02): 217-252. 
Murdie, Amanda M \& David R Davis (2012) Shaming and blaming: Using events data to assess the impact of human rights INGOs. International Studies Quarterly 56(1): 1-16.

Neumayer, Eric (2005) Do international human rights treaties improve respect for human rights? Journal of Conflict Resolution 49(6): 925-953.

O'Keefe, Michael \& Paul D Schumaker (1983) Protest effectiveness in Southeast Asia. American Behavioral Scientist 26(3): 375 -394.

Poe, Steven C \& C Neal Tate (1994) Repression of human rights to personal integrity in the 1980s: A global analysis. The American Political Science Review 88(4): 853-872.

Rasler, Karen (1996) Concessions, repression, and political protest in the Iranian Revolution. American Sociological Review 61(1): 132-152.

Risse, Thomas \& Kathryn Sikkink (1999) The socialization of international human rights norms into domestic practice: Introduction. In: Thomas Risse, Stephen C Ropp \& Kathryn Sikkink (eds) The Power of Human Rights : International Norms and Domestic Change. Cambridge: Cambridge University Press, 1-38.

Ropp, Stephen C \& Kathryn Sikkink (1999) International norms and domestic politics in Chile and Guatemala. In: Thomas Risse, Stephen C Ropp \& Kathryn Sikkink (eds) The Power of Human Rights: International Norms and Domestic Change. Cambridge: Cambridge University Press, 172-204.

Salehyan, Idean; Cullen S Hendrix, Jesse Hamner, Christina Case, Christopher Linebarger, Emily Stull \& Jennifer Williams (2012) Social Conflict in Africa: A new database. International Interactions 38(4): 503-511.

Schumaker, Paul D (1975) Policy responsiveness to protest-group demands. The Journal of Politics 37(2): 488-521.

Simmons, Beth A (2009) Mobilizing for Human Rights: International Law in Domestic Politics. Cambridge: Cambridge University Press.

Smith, Karen E (2013) Acculturation and the acceptance of the Genocide Convention. Cooperation and Conflict 48(3): 358-377.

Stephan, Maria J \& Erica Chenoweth (2008) Why civil resistance works: The strategic logic of nonviolent conflict. International Security 33(1): 7-44.

Teorell, Jan; Nicholas Charron, Stefan Dahlberg, Sren Holmberg, Bo Rothstein, Petrus Sundlin \& Richard Svensson (2013) The Quality of Government Dataset, version 20 Dec13. University of Gothenburg: The Quality of Government Institute (http://www.qog.pol.gu.se).

Vreeland, James R (2008) Political institutions and human rights: Why dictatorships enter into the United Nations Convention Against Torture. International Organization 62(01): 65-101. 
Wood, Reed \& Mark Gibney (2010) The Political Terror Scale (PTS): A re-introduction and a comparison to CIRI Human Rights Quarterly 32(2): 367-400.

KIRSSA CLINE RYCKMAN, b. 1985, PhD in Political Science (University of Arizona, 2012); Assistant Director International Security Studies, University of Arizona (2012- ); research interests: non-state conflict, civil war, protest. 


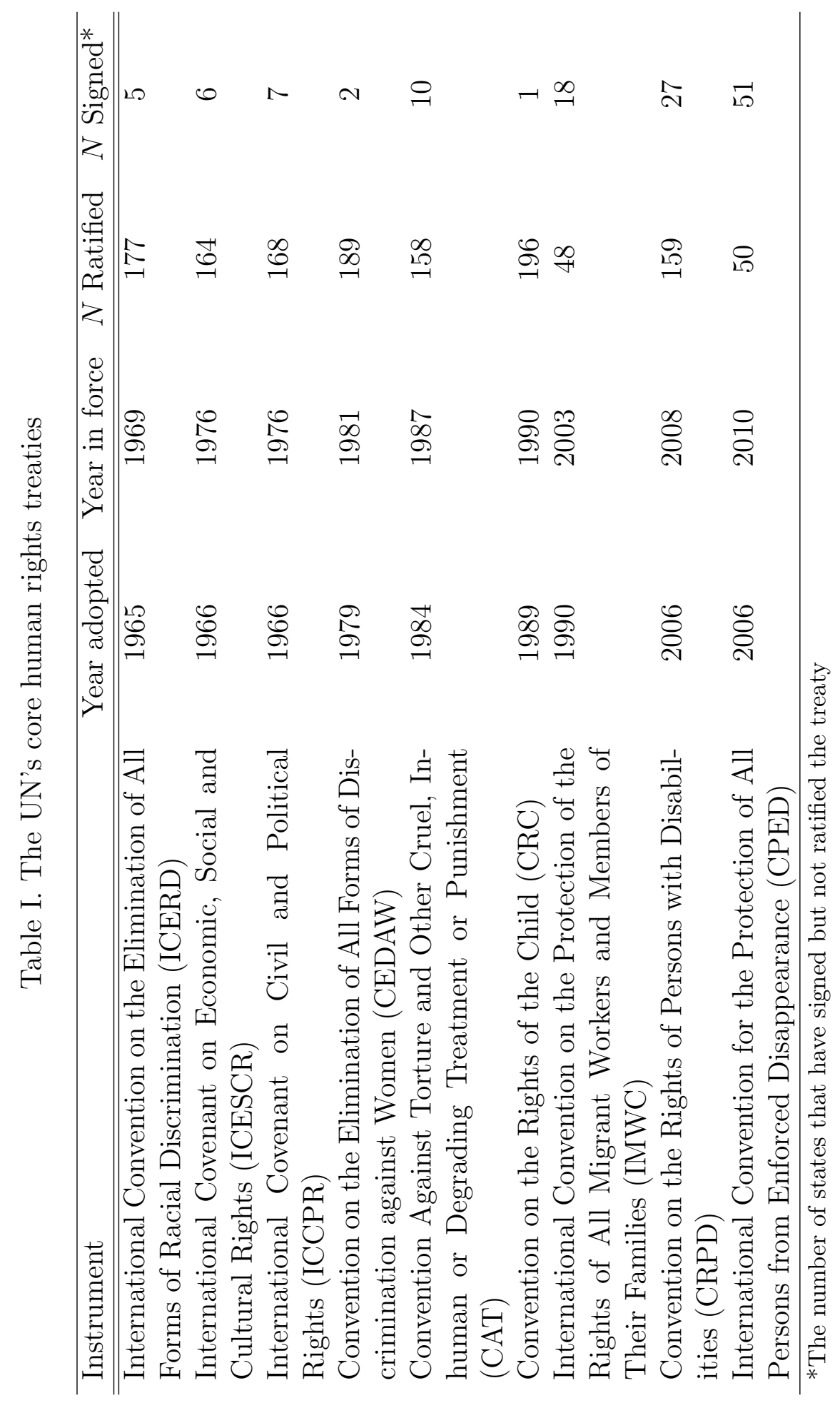


Table II. Summary statistics

\begin{tabular}{lccccc}
\hline Variable & $N$ & Mean & St. dev. & Min & Max \\
\hline \hline Sign & 6,888 & 0.07 & 0.25 & 0 & 1 \\
Ratify & 6,888 & 0.11 & 0.31 & 0 & 1 \\
Nonviolent campaign & 6,888 & 0.03 & 0.16 & 0 & 1 \\
Nonviolent campaign size & 6,845 & 0.053 & 0.39 & 0 & 4 \\
Nonviolent campaign success & 6,883 & 0.01 & 0.09 & 0 & 1 \\
Violent campaign & 6,888 & 0.08 & 0.27 & 0 & 1 \\
Violent campaign size & 6,848 & 0.11 & 0.44 & 0 & 4 \\
Human rights respect & 6,888 & 0.24 & 1.38 & -3.13 & 4.63 \\
Common law & 6,744 & 0.38 & 0.47 & 0 & 1 \\
Regime type & 6,097 & 0.15 & 7.49 & -10 & 10 \\
New democracy & 6,888 & 0.08 & 0.26 & 0 & 1 \\
Number signed & 6,888 & 1.60 & 1.60 & 0 & 6 \\
Number ratified & 6,888 & 2.02 & 1.72 & 0 & 7 \\
\hline
\end{tabular}


Table III. The effect of nonviolent campaigns on treaty commitments

\begin{tabular}{|c|c|c|c|c|}
\hline & $\begin{array}{c}1 \\
\text { Sign } \\
\end{array}$ & $\begin{array}{c}2 \\
\text { Sign } \\
\end{array}$ & $\begin{array}{c}3 \\
\text { Ratify }\end{array}$ & $\begin{array}{c}4 \\
\text { Ratify } \\
\end{array}$ \\
\hline Nonviolent campaign & $\begin{array}{l}0.480^{*} \\
(0.013)\end{array}$ & - & $\begin{array}{l}0.601^{* *} \\
(0.006)\end{array}$ & $\overline{c-}$ \\
\hline Nonviolent campaign size & - & $\begin{array}{c}0.153 \\
(0.054)\end{array}$ & - & $\begin{array}{l}0.183^{*} \\
(0.026)\end{array}$ \\
\hline Violent campaign & $\begin{array}{l}-0.411^{*} \\
(0.041)\end{array}$ & - & $\begin{array}{c}0.196 \\
(0.150)\end{array}$ & - \\
\hline Violent campaign size & - & $\begin{array}{l}-0.287^{*} \\
(0.049)\end{array}$ & - & $\begin{array}{c}0.061 \\
(0.497)\end{array}$ \\
\hline Human rights respect & $\begin{array}{l}-0.005 \\
(0.908)\end{array}$ & $\begin{array}{c}0.003 \\
(0.937)\end{array}$ & $\begin{array}{c}0.050 \\
(0.174)\end{array}$ & $\begin{array}{c}0.048 \\
(0.189)\end{array}$ \\
\hline Common law & $\begin{array}{c}-0.414^{* * *} \\
(0.000)\end{array}$ & $\begin{array}{c}-0.389 * * * \\
(0.000)\end{array}$ & $\begin{array}{c}-0.195^{* *} \\
(0.008)\end{array}$ & $\begin{array}{c}-0.178^{*} \\
(0.018)\end{array}$ \\
\hline Regime type & $\begin{array}{c}0.045^{* * *} \\
(0.000)\end{array}$ & $\begin{array}{c}0.044^{* * * *} \\
(0.000)\end{array}$ & $\begin{array}{c}0.012 \\
(0.057)\end{array}$ & $\begin{array}{c}0.011 \\
(0.074)\end{array}$ \\
\hline New democracy & $\begin{array}{l}-0.300 \\
(0.080)\end{array}$ & $\begin{array}{l}-0.287 \\
(0.095)\end{array}$ & $\begin{array}{c}0.050 \\
(0.714)\end{array}$ & $\begin{array}{c}0.040 \\
(0.762)\end{array}$ \\
\hline Number signed/ratified & $\begin{array}{c}0.062 \\
(0.053)\end{array}$ & $\begin{array}{l}0.067^{*} \\
(0.040)\end{array}$ & $\begin{array}{c}-0.062^{*} \\
(0.013)\end{array}$ & $\begin{array}{c}-0.062^{*} \\
(0.016)\end{array}$ \\
\hline Time since treaty release & $\begin{array}{c}-0.531^{* * * *} \\
(0.000)\end{array}$ & $\begin{array}{c}-0.521^{* * *} \\
(0.000)\end{array}$ & $\begin{array}{c}-0.103^{* * *} \\
(0.000)\end{array}$ & $\begin{array}{c}-0.102^{* * * *} \\
(0.000)\end{array}$ \\
\hline Constant & $\begin{array}{c}-0.921 * * * \\
(0.000)\end{array}$ & $\begin{array}{c}-0.954^{* * *} \\
(0.000)\end{array}$ & $\begin{array}{c}-1.538^{* * *} \\
(0.000)\end{array}$ & $\begin{array}{c}-1.541^{* * *} \\
(0.000)\end{array}$ \\
\hline $\mathrm{N}$ & 5,961 & 5,878 & 5,961 & 5,878 \\
\hline$\chi^{2}$ & $231.59 * * *$ & $238.29 * * *$ & $117.97^{* * *}$ & $103.42^{* * *}$ \\
\hline Log likelihood & -1361.686 & -1333.158 & -1961.570 & -1920.584 \\
\hline
\end{tabular}

Logistic regression coefficients reported, with p-values in parentheses

${ }^{*} p<0.05,{ }^{* *} p<0.01,{ }^{* * *} p<0.001$ 
Table IV. Robustness check: Campaign success

\begin{tabular}{|c|c|c|c|c|}
\hline & $\begin{array}{c}1 \\
\text { Sign }\end{array}$ & $\begin{array}{c}2 \\
\text { Sign }\end{array}$ & $\begin{array}{c}3 \\
\text { Ratify }\end{array}$ & $\begin{array}{c}4 \\
\text { Ratify }\end{array}$ \\
\hline Nonviolent campaign success & $\begin{array}{c}0.161 \\
(0.676)\end{array}$ & $\begin{array}{c}0.190 \\
(0.621)\end{array}$ & $\begin{array}{c}0.698^{*} \\
(0.045)\end{array}$ & $\begin{array}{c}0.715^{*} \\
(0.041)\end{array}$ \\
\hline Nonviolent, no success & - & $\begin{array}{c}0.678^{* *} \\
(0.006)\end{array}$ & - & $\begin{array}{c}0.566^{* *} \\
(0.016)\end{array}$ \\
\hline Human rights respect & $\begin{array}{c}0.030 \\
(0.364)\end{array}$ & $\begin{array}{c}0.039 \\
(0.249)\end{array}$ & $\begin{array}{c}0.022 \\
(0.496)\end{array}$ & $\begin{array}{c}0.029 \\
(0.382)\end{array}$ \\
\hline Common law & $\begin{array}{c}-0.396^{* * *} \\
(0.000)\end{array}$ & $\begin{array}{c}-0.393^{* * *} \\
(0.000)\end{array}$ & $\begin{array}{c}-0.200 * * \\
(0.007)\end{array}$ & $\begin{array}{c}-0.195 * * \\
(0.009)\end{array}$ \\
\hline Regime type & $\begin{array}{c}0.040^{* * *} \\
(0.000)\end{array}$ & $\begin{array}{c}0.042^{* * *} \\
(0.000)\end{array}$ & $\begin{array}{l}0.013^{*} \\
(0.039)\end{array}$ & $\begin{array}{c}0.013^{*} \\
(0.033)\end{array}$ \\
\hline New democracy & $\begin{array}{c}-0.261 \\
(0.124)\end{array}$ & $\begin{array}{l}-0.258 \\
(0.131)\end{array}$ & $\begin{array}{c}0.023 \\
(0.862)\end{array}$ & $\begin{array}{c}0.030 \\
(0.827)\end{array}$ \\
\hline Number signed/ratified & $\begin{array}{c}0.071^{*} \\
(0.025)\end{array}$ & $\begin{array}{c}0.063 \\
(0.053)\end{array}$ & $\begin{array}{c}-0.057^{*} \\
(0.020)\end{array}$ & $\begin{array}{r}-0.060^{*} \\
(0.016)\end{array}$ \\
\hline Time since last release & $\begin{array}{c}-0.532^{* * *} \\
(0.000)\end{array}$ & $\begin{array}{c}-0.531^{* * *} \\
(0.000)\end{array}$ & $\begin{array}{c}-0.104^{* * *} \\
(0.000)\end{array}$ & $\begin{array}{c}-0.103^{* * *} \\
(0.000)\end{array}$ \\
\hline Constant & $\begin{array}{c}-0.955^{* * *} \\
(0.000)\end{array}$ & $\begin{array}{c}-0.967^{* * *} \\
(0.000)\end{array}$ & $\begin{array}{c}-1.504^{* * *} \\
(0.000)\end{array}$ & $\begin{array}{c}-1.519^{* * *} \\
(0.000)\end{array}$ \\
\hline $\mathrm{N}$ & 5,956 & 5,956 & 5,956 & 5,956 \\
\hline$\chi^{2}$ & $218.52^{* * *}$ & $225.52^{* * *}$ & $106.37 * * *$ & $119.62^{* * *}$ \\
\hline Log likelihood & -1365.450 & -1362.755 & -1963.647 & -1961.459 \\
\hline
\end{tabular}


Table V. Campaign size as a determinant of repression

\begin{tabular}{lcc}
\hline & Model 1 & Model 2 \\
\hline \hline Campaign size & $-0.455^{* *}$ & $-0.375^{*}$ \\
& $(0.002)$ & $(0.015)$ \\
Radical flank & 0.615 & 0.233 \\
& $(0.316)$ & $(0.671)$ \\
Regime change goal & -0.135 & -0.258 \\
& $(0.800)$ & $(0.587)$ \\
External regime support & 0.019 & 0.844 \\
& $(0.083)$ & $(0.114)$ \\
INGO campaign support & 0.699 & 0.220 \\
& $(0.164)$ & $(0.650)$ \\
Lagged repression & - & $1.060^{* * *}$ \\
& & $(0.000)$ \\
\hline Cut 1 & -1.828 & -0.601 \\
Cut 2 & -1.551 & -0.278 \\
\hline N & 166 & 166 \\
$\chi^{2}$ & $14.17^{*}$ & $44.31^{* * *}$ \\
Log pseudolikelihood & -100.742 & -90.472 \\
\hline
\end{tabular}

Ordinal regression coefficients reported, with p-values in parentheses

${ }^{*} p<0.05,{ }^{* *} p<0.01,{ }^{* * *} p<0.001$ 


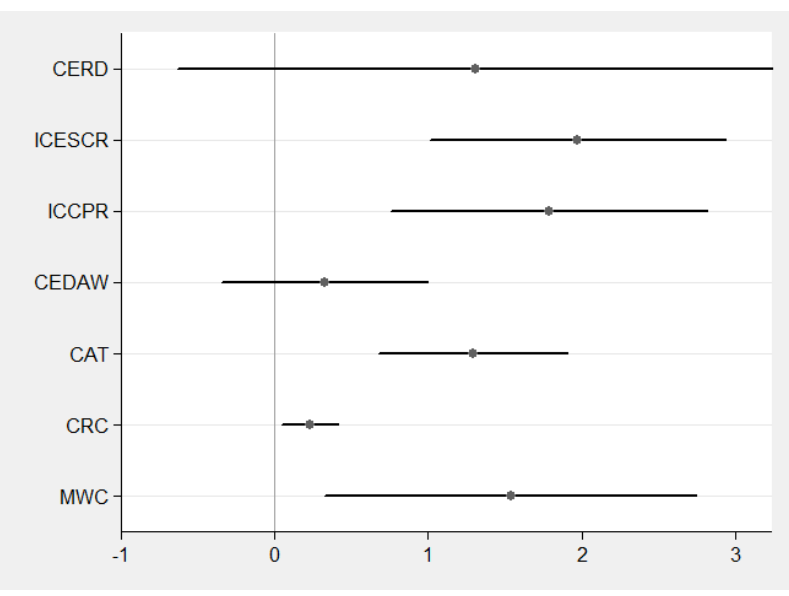

(a) Nonviolent campaign

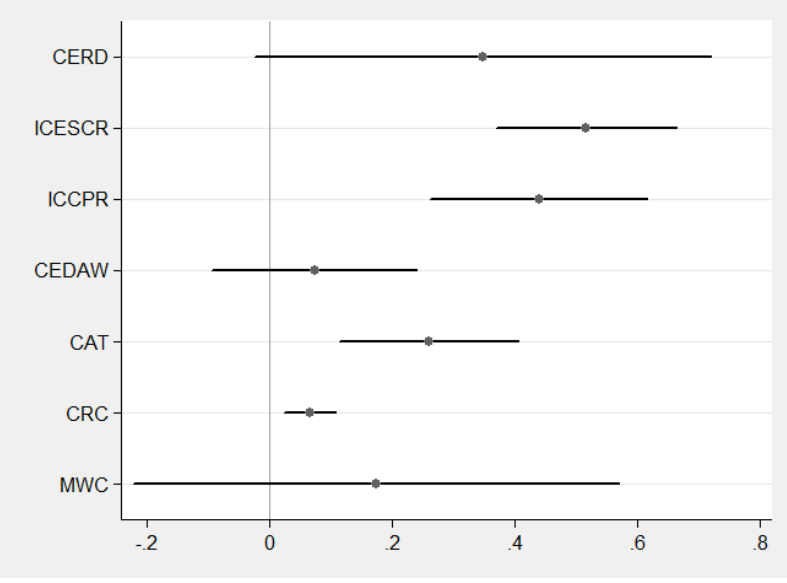

(b) Nonviolent campaign size

Coefficients of the individual Cox models, with $90 \%$ confidence intervals

Figure 1. Effect of nonviolent campaigns on the signature of human rights treaties 


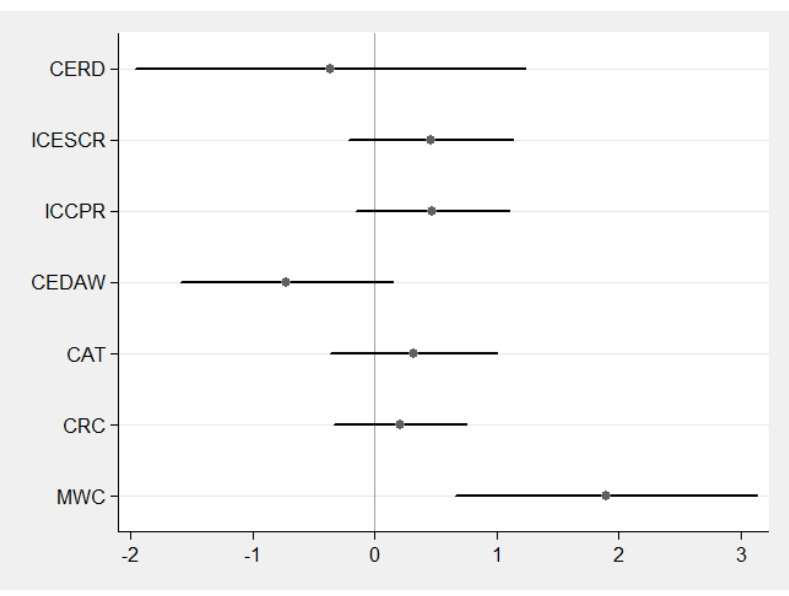

(a) Nonviolent campaign

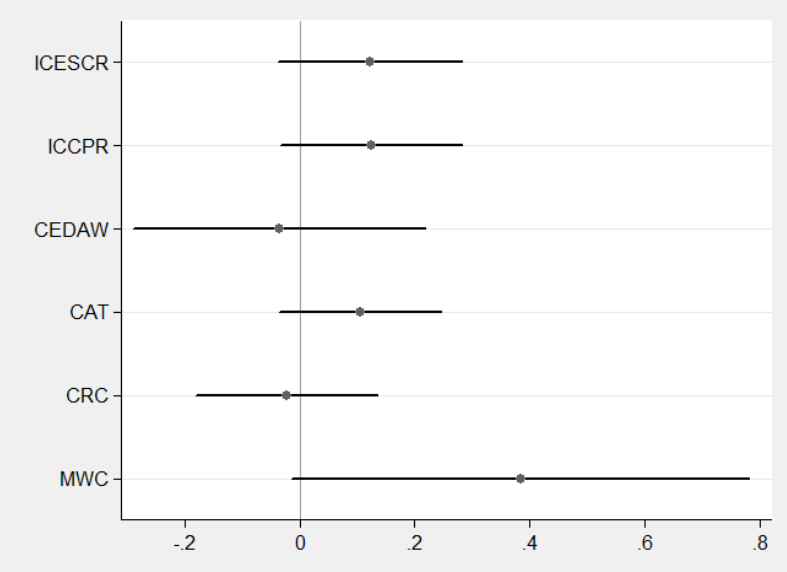

(b) Nonviolent campaign size

Coefficients of the individual Cox models, with $90 \%$ confidence intervals

Figure 2. Effect of nonviolent campaigns on the ratification of human rights treaties 